\title{
最近の水河学
}

一わが国の研究を中心にして一

樋口敬二*

\section{Recent Studies on Glaciers by Japanese Glaciologists}

\section{Keiji HIGUCHI}

\section{I. まえがき}

まず，最初にひととと注橎を加えておいた方がいいと思われるのは，氷河学という言葉である。承河 (Glacier) と似ているために，Glaciology が水河学を意味すると考えている人もあるが，Glaciology は， ラテン語の Glacies（水）を語源としおり，ひろく雪と氷を研究する雪水学を意味している。

水河学に対応する言葉は, 英語にはなく,ドイツ語の Gletscherkunde がてれに当る。

さて, そのような雪水学, 承河学の歴史はずいぶん古いが, てれらが地球科学の一環としてめざましい 発展をとげたのは, こて20年ばかりのととであり, その発展には次のような要因が働いていたと考えられ る。

第一は，国際地球観測年（（Ｇ））以来，とみに活発になった国際観測事業の推進である。氷河につい ていえば，1965年にはじまった国際水文学十年計画（I H D ），およびそれにつづいて現在も実施されて いる国際水文学計画（I H P) が, 観測, 研究に大きな貢献をした。

第二は, 人工衛星の利用である。広域にわたる雪水の分布や, 高山における氷河の存在は, 人工衛星の 映像によって，その全体像がはじめて把握されるようになった。

第三は, コンピュータの使用によって, 承河の流動, 形態に関する数值シミュレーションが可能となり, 大気・海洋・陸水系, なかでも, 気候変動や環境変化にかかわる大気・海洋・雪水圈 (Cryosphere) 系に 関する数值モデルに雪水が組みてまれるようになった。

第四は, グリーンランド, 南極に存在する大陸水床の深首掘削によって得られる水試料の分析によって, 古気候, 古環境の復元が可能となり, 気候変動の研究に貢献するとてろが大きくなった。

てのような要因によって, 雪水学, なかでも水河学は, 地球科学, 特に大気・海洋・陸水系の科学にお いて重要な部分をしめるようになった。また，一方，地球以外の天体における雪水体の状態か宇宙探査機 によって観測され，宇宙雪水学という視点が生れたのに対応して，地球上における雪水についても地球雪 氷学という視点が成立し, 両者が相互に影響を与え合いながら発展してゆくてとが期待されている（樋口 1980 : 前野 1980, 1981)。

以上のような展開をみせている氷河学の最近の動向を, わが国の研究者によっておてなわれた調査, 観 測, 研究の成果を中心にして述べてみたい。

\section{II. 水河の分布}

氷河の観測は，スイスなどでは前世紀から実施されてきたが，地球全域にわたる氷河の分布が観測され

* 名古屋大学水圈科学研究所 Water Research Institute, Nagoya University, Nagoya. 
るようになったのは，1965年からはじまった国際水文学十年計画（I H D ）以来のととである。この計画 の一環として, 国際測地学地球物理学連合 ( I U G G) の国際水文科学協会 ( I A H S) の国際雪水専門 委員会（ＩＣＳＩ）がつくったガイドブック（I H A S 1970）にしたがうて, 各国が共通の分類, 方法 で氷河を記載する「水河台帳」(Glacier Inventory) を作成し，てれらを集積して世界氷河台帳をつくる という計画が提唱された。その結果，1979年には18ケ国において，32地域について氷河台帳が作成された が（I A H S 1979），てれを世界全体としてまとめるには至っていない。

日本では, 文部省海外学術調查「ネパール・ヒマラヤ氷河学術調查」の一環として, エベレスト周辺の ドウド・コシ (Dudh Kosi) 地域の氷河台帳を作成した（HIGUCHI et al.1978，1979)。乙れは, 調查の
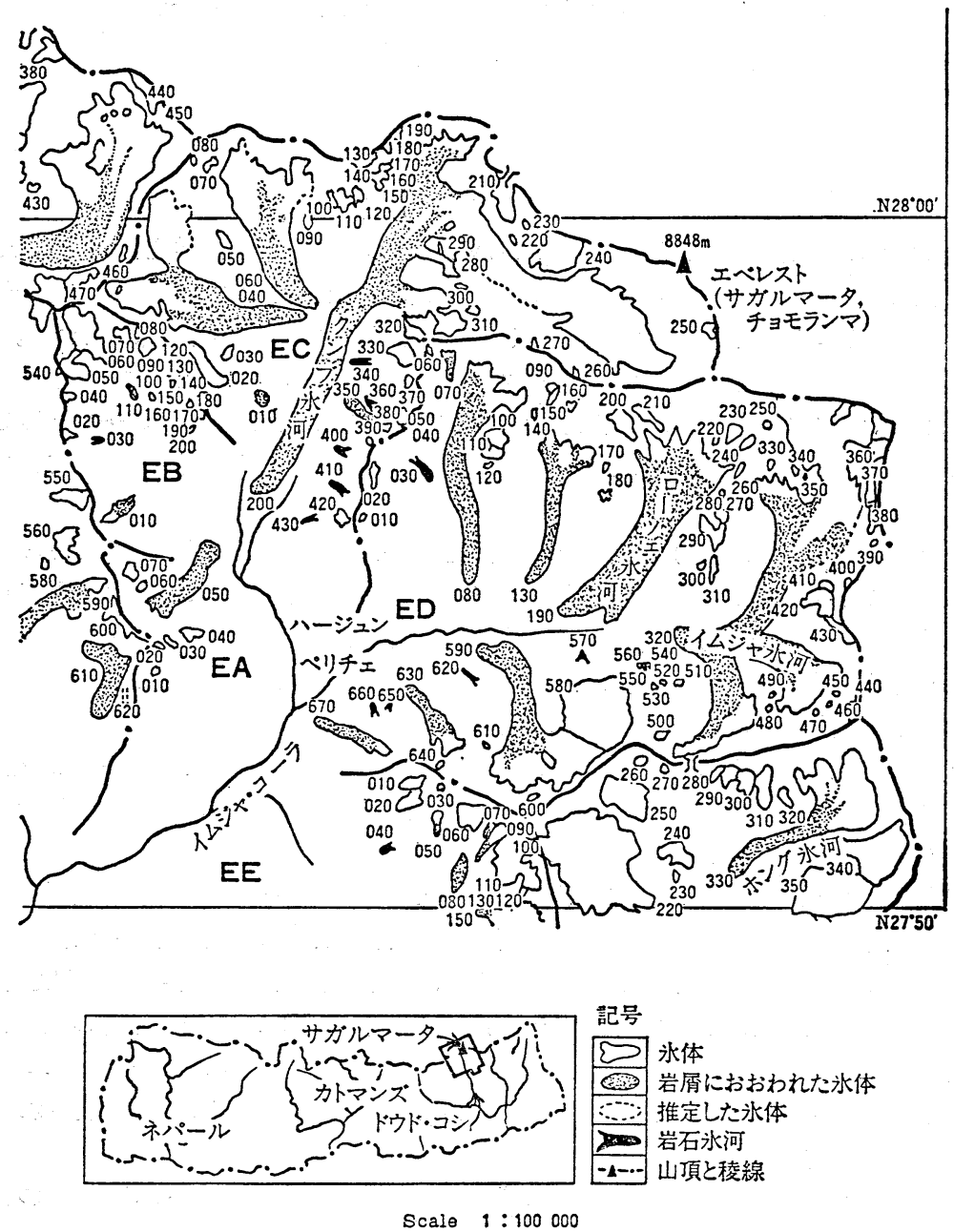

Scale $1: 100000$

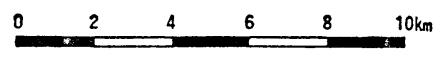

第1図 東ネパールのエベレスト周辺のドウド・コシ地域の氷河台帳の一部 (点が打ってあるのは, 消粍域が岩首でおおわれている水河である。原 図は英語であるが，日本語に書き換えてある。HIGUCHI et al.1978) 
一環として撮影した同地域の水河の航空写真と地上観測の結果を, Schneider の 5 万分 1 地図「Khumbu Himal」(1965), 「Shorong Himal」(1974) と対比して, 水河の位置, 方向, 長さ, 面積, 上端高度, 末 端高度, 傾斜, 分類, 記載事項などをまとめ, Royal Geographic Society の10万分 1 地図「Mount Everest Region」に記入して作成したものである。第1図は，その一部である。

ての水河台帳は, 航空写真撮影を実施した1974〜76年の水河の状態を記録したものであるが，その前に 1955〜63年に撮影された航空写真にもとづいて作った MÜLLERによる同地域の水河台帳（ＩＡ H S 1970） と比較すると，岩屏（debris）におおわれていない水河では，大部分が縮少している。

一方, 水河ではないが, それに近い多年性雪水体である日本の北アルプスの雪溪についても，I H Dの 一環として, 航空写真の撮影をおてない，それと地図にもとづく雪溪台帳が作成されている（HIGUCHI et al. 1980)。ただし, 多年性雪溪の場合, 年による変動がはげしいので, 年でとに台帳をつくる必要が ある。

とてろで, 近年, 人工衛星, なかでもアメリカの Landsat そよって地表の鮮明な映像が得られるよう になって, 地形図がない地域の水河についても詳細な情報が得られるようになった。そてで, アメリカの 地質調查所 (U S G S) の水資源部の提唱によって, Landsat の映像にもとづく『氷河の人工衛星映像地 図』の作成が1978年からはじめられた。

対象は, 南極を含む世界全地域にわたり, ソ連, 中国を含む20ケ国の研究者が協力して, U S G S の提 供する映像を解析して, 世界の水河地図を作成した。その成果は, U S G S の出版物として近く刊行され る予定であり, 日本は, てのうちネパール・ヒマラヤとカラコラムを担当した (HIGUCHI, WATANABE et al. 未発表)。

\section{III. 水河の変動}

さきに述べたように，同じ地域について異なった期間に作られた氷河台帳を比較するてとによって，氷 河末端の前進, 後退の広域にわたる傾向を知るてとができるが, 水河台帳の作成は, 手間がかかるため, 数年間隔になってしまい，年による変動を把握するてとがむつかしい。

そこで, I HD計画では, 氷河台帳の作成平行して, 氷河変動の観測を事業の一つとして推進し, や はり国際雪氷専門委員会がガイドブックを作成して，観測方法の統一をはかった。

もっとも, 氷河変動の観測は, それ以前から国際学術連合（ＩＣＳＵ）の永続観測 (Permanent Service on the Fluctuation of Glaciers) として, 断続的に実施され, 報告書も刊行されてきたので, てれに I HD, I H Pの一環としての意味を持たせて, 両者の共同事業として進められている。日本からも，国 内の多年性雪溪, ネパール・ヒマラヤの水河の変動てついて報告をおてなっている。

たとえば，さきに紹介した氷河台帳を作成した東ネパールのドウド・コシ地域において14の小さな水河 の未端位置を観測した結果，1970７8年の期間では，縮少している水河が 8 で半分以上であり，あとは定 常状態にあるもの3, 拡大しているもの3で, 氷河台帳の比較によってわかったのと同じように, 後退が 主な傾向であった（FUSHIMI et a al. 1981)。

\section{IV. 水河の質量収支と熱収支}

前節で述べたように，気候条件の変動に応答して氷河は拡大，縮少の変動をしているが，てれにしたが って氷河末端位置が低くなったり, 高くなったりする。てれを氷河末端の前進 (advance), 後退 (retreat) というが, 乙れは未端位置の変化をさすものであり, 水河の流動をさすものではない。いうまでもないて とだが, 水河の流動は, 高所から低所へ, すなわち前進, または停止で, 後退はない。

このように氷河末端の変動が起るのは, 氷河の質量の増加（涵養一accumulation）と減少（消耗一 ablation）との間の収支 (balance) に依存している。涵養とは，降雪，なだれ，吹きだまりなどによって 
起る質量の増加であり, 消耗とは, 融解, 蒸発, 破壊などによってもたらされる質量の減少である。

一年で集計した結果，涵養が消耗を上廻る区域を涵養域といい，主として氷河の上流部がてれにあた

る。逆に，消耗が涵養を上廻る区域を消耗域といい，主として氷河の下流部がてれにあたる。

だから, 氷河とは, 涵養域で蓄積された雪水が流動によって消耗域へ運ばれ, 失われてゆく過程といっ てよい。したがって，氷河全体にわたる涵養の総計が，消耗の総計を上迴る，すなわち質量収支（mass balance）がプラスの年がつづくと，涵養域から流動によって送りてまれる質量が，消耗域で失われてゆ く質量を上迴るようになり，消耗域が拡大し末端の高度が低くなる。乙れが氷河末端の前進である。後退 は,とれと逆の過程で起される。

そこで, 冰河変動の機構を理解するには, 氷河の涵養, 消耗, 流動, 質量収支, および消耗と関係の深 认雪氷面上の熱収支などを支配する要因を知る必要がある。

まず，涵養であるが，その主な過程が何であるかは，地域によって異なる。多くの場合，降雪が主であ るが, ヒマラヤの大きな氷河では急峻な岩壁で起る雪崩も涵養に貢献するし, 日本の雪溪では, 降雪より 吹きだまりの寄与が大きい場合がある。

また, 消耗についても, 主な熱源が何であるかは, 地域によって異なる。南極のように日射が主要であ る場合もあるが，多くは，日射と空気からの熱伝達とが主な熱源である。ただし，日本の雪溪やノルウエ 一南部の氷河のように, 海岸に近い場合には, 雪氷面に対する水蒸気の凝結に伴って放出される潜熱が, 大きな寄与をするとともある。

そこで, 氷河の質量収支, 熱収支の地域特性を明らかにするととも，I H Dおよび I H P計画の一つに とりあげられ, やはり国際雪水専門委員会がガイドブックをつくり, 各地域の氷河の特性を比較できるよ うに，世界各地を結ぶつぎのような三つのチエーンに沿う氷河の観測を国際協力によって実施した。

南北チエーンは, 南北アメリカ大陸を縦断して, 北のアラスカから南の南極半島までを結ぶ線上になら ぶ水河である。東西チェーンの第一は, $35^{\circ} \mathrm{N} \sim 55^{\circ} \mathrm{N}$ 範囲にあって, 天山, パミ一ル, コーカサス, ア ルプス, ロッキーとつづく一連の山域にある氷河である。東西チエーンの第二は, ほぼ $65^{\circ} \mathrm{N}$ の線に沿っ て, ウラル北部, スカンジナビア, アイスランド, カナダ北部, アラスカといった北極圏の氷河である。

てれらの観測の成果は，1979年に取りまとめがおてなわれたが，当初の目的を達成したとはいいがた く, 今後の継続観測がのぞまれる。しかし，I H P 計画においては, 組織的な観測は,おてなわれていな 认。

日本の研究者による氷河調査においても, 質量収支, 熱収支にかかわる観測は, 南極, アラスカ, ヒマ ラヤ, カラコラム, パタゴニア, 中国などの地域の氷河において実施されているが, それらについては, 巻末にあげる調査報告, 総合報告を参照していただきたい。

ただ，質量収支，熱収支の地域特性の例として，ネパール・ヒマラヤの氷河の場合をあげておく。 ヨーロッパ, 北アメリカの水河では, 主要な涵養は降雪であるため, 冬期に起り, 主要な消耗は融解で あるため, 夏期に起る。したがって，てのような水河では，質量収支が二季節に依存している。

てれに対して, ヒマラャの氷河は, モンスーン地帯にあるため, 夏期に涵養域では降雪, 雪崩が起り, 消耗域では融解が起っており, 質量収支は, 夏季の一季節に依存している。

てのように, ヒマラャの氷河の質量収支は, I HDのガイドブックの基本になっているヨーロッパ・ア メリカの氷河の場合とは, たいへん異なっており, しかも, 観測, 研究がほとんどおてなわれていなかっ た。そこで, 上田（1983）は，てれを夏季涵養型氷河とよび，ネパール・ヒマラャ氷河学術調査の観測結 果にもとづいて, その特性を明らかにし，国際的に高い評価を得ている。

一方, 熱収支に関して，ネパール・ヒマラャの氷河の特徴をあげると，エベレスト地域の長大な水河で は, 第 1 図に示したように, 消耗域が岩屑（debris）によっておおわれ, それによって熱収支が支配され ている。とのような水河は, ヒマラャだけではなく, パミール, アンデス, ロッキーなどの地域にも存在 
しているが,くわしい調查と解析はおてなわれていなかった。

そこで, 渡边らは, クンブ氷河において詳細な観測をおてない（WATANABE et al. 1980), 岩屑の分

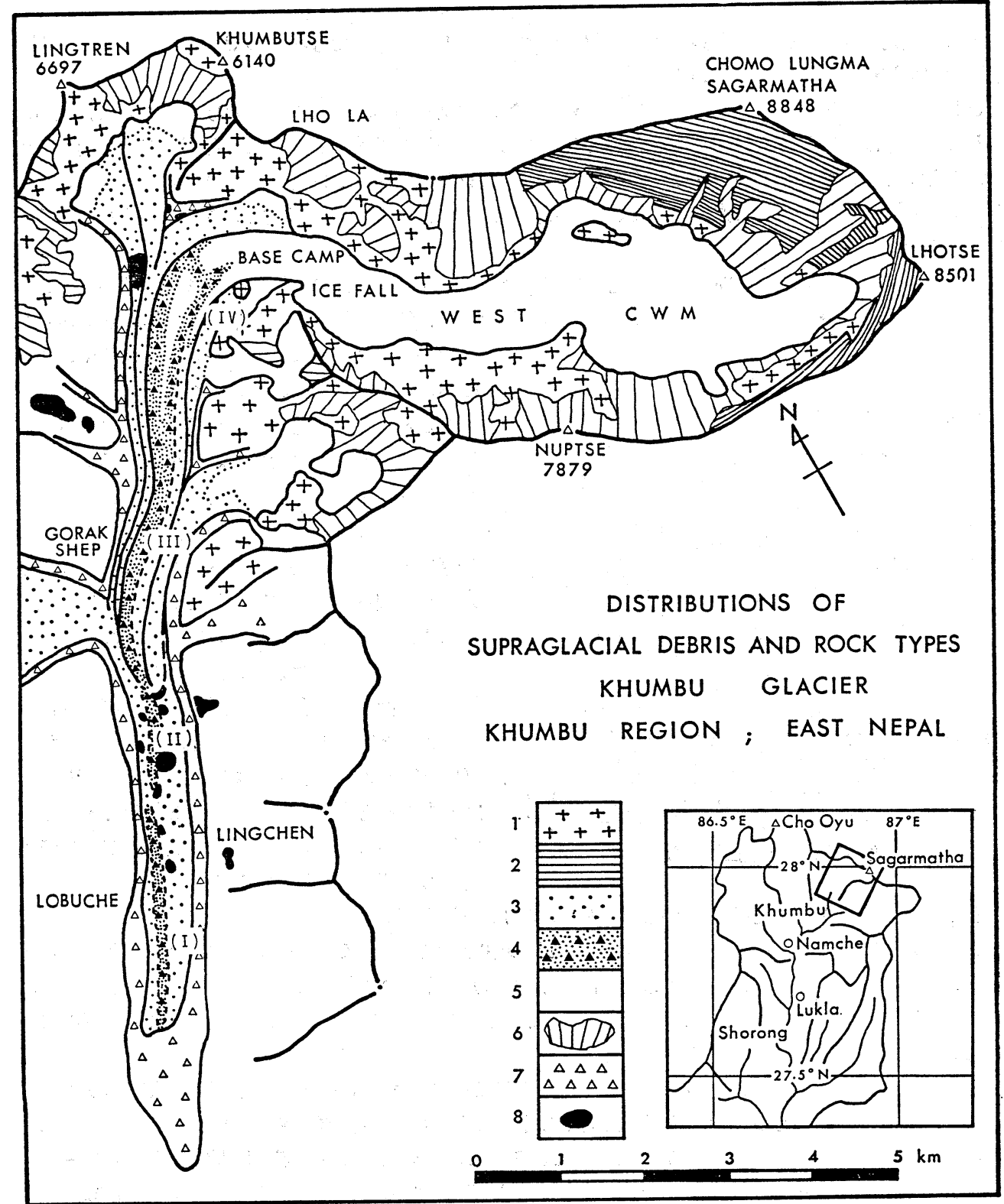

1) granitic rocks, 2) schistose rocks, 3) supraglacial granitis debris, 4) supraglacial schistose debris, 5) debris-free part, 6) snow cover, 7 ) side- and end-moraines and 8) ponds and lakes.

第 2 図 東ネパールのエベレスト付近のクンブ氷河における氷河上岩屑と岩石型の分布 (FUSHIMI et al. 1980) 
布, 起源, 熱収支への影響を明らかにした。第 2 図は, クンブ氷河における水河上岩屑と周辺の岩石型の 分布図である。

\section{V. 水河の流動と数值モデル}

氷河の変動過程において流動がしめる役割りが大きいととはいうまでもないので，てれまで多くの調查 観測や理論解析がおてなわれている。

しかし, 氷河の表面流速の観測は比易的容易で, 観測例は多いが, 承河内部における流速分布, 底面滑 りとなると, 観測例があまり多くない。そてで, てれらの結果と理論的研究とにもとづいて, 氷河の数值 モデルをつくり, コンピューターの利用によって, 数值シミュレーションをおてない, 流動過程を理解し ようとする研究が最近大いに進んでいる。しかし，わが国は，ての方面の研究でやや立ちおくれているの で, 今後の推進がのぞまれる。

一般に氷河の流動速度は, ゆっくりしたもので, Budd らが世界各地の氷河における観測結果をまとめ $\tau$, 水河の水厚, 表面傾斜, 表面流速の関係を示したように（第 3 図）, 表面流速は年間数 $10 \mathrm{~m}$ から数 $100 \mathrm{~m}$ ていどであり，ネパール・ヒマラヤの水河

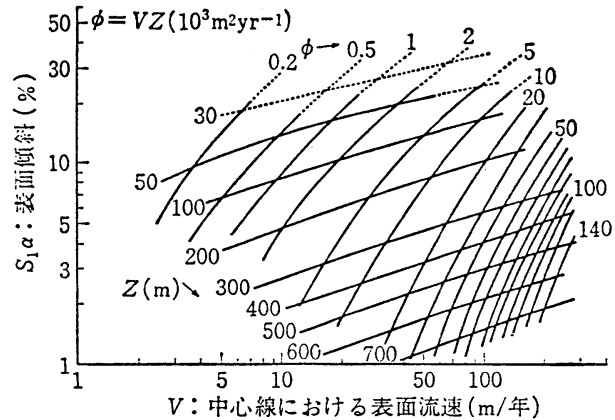

第3図世界の水河における水厚, 表面傾斜, 表面流速の関係 (BUDD and ALLISON 1975) $Z:$ 水厚 $(\mathrm{m}) . \phi:$ 単位幅あたりの 年間流量, $S_{1}$ : 表面傾斜, $\alpha:$ 氷河の形 によってきまる補正係数. における観測結果も, その程度である。

ところが，文部省海外学術調査「パタゴニア地 域水河学術調査」において, 成瀬ら（1985）がサ ン・ラフアェル氷河において測定したととろによ ると, 表面流速は上流部で $13 \mathrm{~m} /$ 日, 末端部で 17. $5 \mathrm{~m} /$ 日という大きな值が得られた。しのように早 い流動か起っている原因としては, 融解量が大き いために氷河底面と基盤との間に水が豊富で潤活 的作用をしているためと考えられている。

また，南極の昭和基地に近い白瀬水河でも，年 間2500mという大きな表面流速が観測されており

(NAKAWO et al. 1978 ; FUJII 1981), 南極水 床でももっとも早く流動している部分であろうと いわれている。そして, それに関連して, 白瀬氷 河, およびその背後に広がるみずほ高原氷床の不

安定性 (instability) が論じられている（MAE 1979 ; 成瀬 1980)。

てのような水河の不安定性に関連して, 承河現象の中でも注目されているのは, 氷河サージとよばれる 現象である。さきに述べたように，氷河の流速は，10m/日くらいになると異常に早い水河とされるのだ が, 氷河サージは, $100 \mathrm{~m} /$ 日というような流動が突如として起る, いわば, 氷河の雪崩のような破壊的現 象である。

氷河サージの発生については, アラスカで組織的調查がおてなわれ，数多くの水河で過去に起ったてと がわかっているが, 現象そのものを観測した例はでく少なく,パミール高原のメドベデ氷河で Dolgoushin ら（1975）が観測した結果が貴重な記録となっている。ての氷河は，12〜14年の周期性をもってサージを 起すため, 現象の実態をとらえるように観測の準備をしておいたので, サージ前後の氷河の状態について 詳細なデータが得られている。

そして，それらのデータにもとづいて，BUDD と JENSSEN（1975）は，数值モデルをつくり，氷河サ 一ジの周期的発生を説明した。

てのような山岳水河のサージは，付近の地域に災害を与えるが, その影響は局所的である。とてろが, 最 
近話題になっているのは, 南極水床にお けるサージの発生である。BUDD ら (19 76) は, 東南極水域境界からミルヌーイ 基地至る断面について氷河サージが起 った場合と起らない場合の二つについて 数值シミュレーションをおてない, 第 4 図のように現在の表面形態はサージが起 った場合に近いてとを示した。そてで， 前たち（1979）は，白瀬水河について上 にあげたような異常に大きい流速から氷 河サージ発生の可能性を論じている。

一方, 西南極氷床については, 基盤の 大部分が海面下にあるため, 海水面の影 響による不安定性が論じられている。大 気中の $\mathrm{C} \mathrm{O}_{2}$ の増加などによって気候が 温暖化すると, 海水温が上昇して, 融解 が進む結果, 西南極水床は 分裂して, 100年 以内に消失し，そのために海水面 は $7 \mathrm{~m}$ 上昇をひきおてすという計算があ る (THOMAS and BENTLEY 1978)。 このような海水面の上昇は, 海岸線付 近に密集している都市に大きな影響を与 えるため, 西南極水床の不安性は, “雪

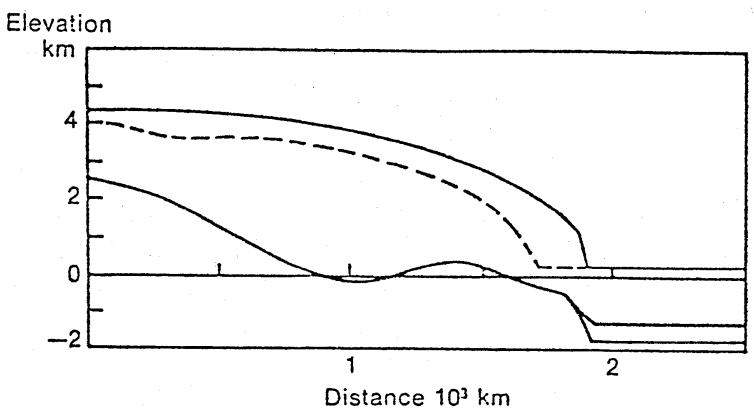

Elevation

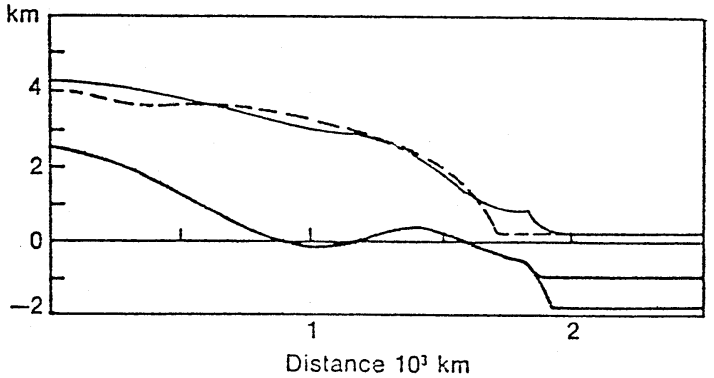

第 4 図 南極水床の東南極水域境界からミルヌー亿基地に至 る氷床の表面形態に関する計算（実線）と実測

（破線）との比較（上がサージのない定常状態の場 合, 下がサージのある場合, BUUDD and MC INNES 1976) 氷学において最大の未解決課題”といわれている。

\section{VI. おわりに}

以上のほか, 気候変動における南極水床の役割り, 南極, グリンランドの大陸水床の深層掘削によって 得られた氷試料の分析による古環境の復元などが, 最近の水河学における重要な研究課題であるが, 日本 では南極関係の研究者によって進められているので, てれについては, 国立極地研究所『南極の科学 4 氷と雪』(1983) を参照していただきたい。

一方, 最近の水河学の重要な研究課題として, 水河の水資源的利用がある。チベット高原の河川のよう に, 乾燥地域の河川にあっては流量の半分以上が水河からの融解水である場合も多いからである。そのた めに, 調査研究が活発に進められており, 特に国際雪水專門委員会（ＩＣＳＩ）では, 「水河流域の流出 予測に関する作業委員会」を組織して, さきに紹介した I H D, I H P 計画にわいて蓄積された氷河台 帳, 水河変動, 質量収支, 熱収支などに関する観測結果を水資源的利用に生かす応用的研究をおてなって いる。その成果については, 最近, 刊行されたので（I A H S Publication №. 149, 1985), 参照してい ただきたい。

このように，ヒマラヤ，チベット高原，天山山脈など，中央アジアの高地に存在する氷河は, 気候の違 いを反映して, その形態, 質量収支, 熱収支, 気候変動に対する応答などの特性が多様であり, 地球科学 的に興味ある研究対象であるとともに, 水資源として地域社会に密接な関係をもっている。そてで, 日本 の研究者も, ネパールのトリビューバン大学, 灌溉水文気象局, 中国の中国科学院水河凍土研究所の研究 
者と協力して, 調査研究を進めている。特に, 1985年からは, ヒマラヤ, チベット高原, 天山山脈の氷河 の地域特性を明らかにする文部省海外学術調查「アジア高山地域における比較氷河研究」が開始され, 研 究の一層の発展が期待されている。

\section{引用文献}

上田豊（1983）：ネパール・ヒマラヤの夏季涵養型水河における質量収支の特性 I， I．雪水，45, 2. 81-105.

BUDD, W. F. and I. F. ALLISON (1975) : An empirical scheme for estimating the dynamics of unmeasured glaciers. IAHS Publ., №. 104, 246-256.

BUDD, W. F. and D. JENSSEN (1975) : Numerical modelling of glacier systems. IAHS Publ. No. 104, 257-291.

BUDD, W. F. and B. J. MC INNES (1970) : A movie film illustrating the numerical modelling of periodically surging ice masses. Meteorology Department, Univ. Melbourne, Publ., №. 21.

Dolgoushin, L. D. and G. B. Osipova (1975) : Glacier swrges and the problem of their forecasting IAHS Publ. No. 104, 292-304.

FUJII, Y. (1981) : Aerophotographic interpretation of surface features and an estimation of ice discharge at the outlet of the Shirase drainage basin, Antarctica, Nankyoku Shiryô (Antarct. Rec.), 72, 1-15.

FUSHIMI, H, et al. (1980) : Distributions and grain sizes of supraglacial debris in the Khumbu glacier, Khumbu region, East Nepal. Seppyo, 41, Special issue, 18-25.

FUSHIMI, H. et al. (1981) ; Recent fluctuations of glaciers in the eastern part of Nepal Himalayas, IAHS Publ., No. 131, 21-28.

樋口敬二 (1980)：地球雪水学. 地球, 2 ( 3 ), 175-179.

HIGUCHI, K. et al. (1978) : Preliminary report on glacier inventory in the Dudh Kosi region. Seppyo, 40, Special Issue, 78-83.

HIGUCHI, K. et al. (1979) : Glacier inventory in the Dudh Kosi region, East Nepal. IAHS Publ., No. $126,95-103$.

HIGUCHI, K. et al. (1980) : Inventory of perennial snow patches in Central Japan. Geo Journal, 4 ( 4 ), 303-311.

MAE, S. (1979) : The recent variation of ice sheet, Mizuho Plateau, East Antarctica. J. Glaciol., 24, 53-61.

前野紀一 (1980)：宇宙雪水学. 地球, 2 (3) 250-256.

前野紀一 (1981) : 水の科学. 北海道大学図書刊行会, 187-213.

NAKAwO, M. et al. (1978) : Discharge of ice across the Sôya Coast. Mem. Natl Inst. Polar Res., Spec. Issue, 7, 235-244.

成瀬廉二 (1980)：南極水床の不安定性. 地球, 2 (3) 237-242.

NARUSE, R. (1985) : Flow of Soler glacier and San Rafael glacier. Glaciological Studies in Patagonia Northern Icefield. Data Center for Glacier Research, Japanese Society of Snow and Ice, 64-69.

ThomAS, R. H., and C. R. BENTLEy (1978) : A model for Holocene retreat of the west Antarctic Ice Sheet. Quatern. Res, 10 (2), 150-170.

WATANABE, O. et al (1980) : Outline of studies on supraglacial debris of the Khumbu glacier, Khumbu region. Seppyo, 41, Spec. Issue, 5-8.

\section{参考文献}

前述の引用文献に加えて, 総合報告, 学術書などの主なものを順不同にあげておく。

1) "Glaciers and Climates of Nepal Himalayas - Report of the Glaciological Expedition of Nepal一”, Part I （1976）～Part II （1980）, 日本雪水学会水河情報センター. 
2）安成哲三・藤井理行著，（1983）：『ヒマラヤの氷河と気候』, 東京堂出版.

3）“Glaciological Studies in Patagonia Northen Icefield, 1983-1984”, (1985) 日本雪水学会水河情 報センタ一。

4）国立極地研究所（1983）:『南極の科学 4 水と雪』.

5）『雪氷の研究展望と文献目録 1969 1978』（1982），雪水の研究 No. 6，日本雪水学会の水河. 雪溪の項.

6) IAHS Publication No. 126 (1980) : "World Glacier Inventory".

7) IAHS Publication No. 138 (1982) : "Hydrological Aspects of Alpine and High-Mountain Areas".

8) IAHS Publication No. 149 (1985) : “Techniques for Prediction of Runoff from Glacierized Areas".

9) RADOK, U. (1978) : “Climatic Roles of Ice”, UNESCO, Paris.

10) MEIER, M. F. (1983) : Snow and Ice in a Changing Hydrological World, Hydrological Sciences, 28, 1, 3-22. 